\title{
An Outcome Measure of Functionality and Pain in Patients with Low Back Disorder: A Validation Study of the Iranian version of Low Back Outcome Score
}

\author{
Parisa Azimi ${ }^{1}$, Hossein Nayeb Aghaei ${ }^{1}$, Shirzad Azhari ${ }^{1}$, Sohrab Shazadi ${ }^{1}$, \\ Hamid Khayat Kashany ${ }^{1}$, Hassan Reza Mohammadi ${ }^{1}$, Ali Montazeri ${ }^{2}$ \\ ${ }^{1}$ Functional Neurosurgery Research Center, Shahid Beheshti University of Medical Sciences, Tehran, Iran \\ ${ }^{2}$ Mental Health Research Group, Health Metrics Research Centre, Iranian Institute for Health Sciences Research, \\ Academic Center for Education, Culture and Research (ACECR), Tehran, Iran
}

\begin{abstract}
Study Design: Cross-sectional study.
Purpose: This study aimed to cross-culturally translate and validate the low back outcome score (LBOS) in Iran.

Overview of Literature: Lumbar disc hernia $(\mathrm{LDH})$ is the most common diagnoses of low back pain and imposes a heavy burden on both individual and society. Instruments measuring patient reported outcomes should satisfy cetain psychometric properties.

Methods: The translation and cross-cultural adaptation of the original questionnaire was performed using Beaton's guideline. A total of 163 patients with LDH were asked to respond to the questionnaire at three points in time: preoperative and twice within 1-week interval after surgery assessments. The Oswestry disabilty index (ODI) was also completed. The internal consistency, test-retest, convergent validity, and responsiveness to change were assessed. Responsiveness to change also was assessed comparing patients' pre- and postoperative scores.

Results: The mean age of the cohort was 49.8 years (standard deviation=10.1). The Cronbach's alpha coefficients for the LBOS at preoperative and postoperative assessments ranged from 0.77 to 0.79 , indicating good internal consistency. Test-retest reliability as performed by intraclass correlation coefficient was found to be 0.82 (0.62-0.91). The instrument discriminated well between subgroups of patients who differed in the Finneson-Cooper score. The ODI correlated strongly with the LBOS score, lending support to its good convergent validity $(r=-0.83 ; p<0.001)$. Further analysis also indicated that the questionnaire was responsive to change $(p<0.001)$. Conclusions: The Iranian version of LBOS performed well and the findings suggest that it is a valid measure of back pain treatment evaluation among LDH patients.
\end{abstract}

Keywords: Iran; Low back outcome score; Validity; Low back pain

\section{Introduction}

Low back pain is the most common type of back pain [1], mainly caused by lumbar disc herniation (LDH) [2]. Low back pain is a major problem globally, with the highest prevalence during the life span [3]. It preludes a poorer quality of life for individuals, but also increased absenteeism and early retirement [4]. A variety of tools are avail-

Received Dec 21, 2015; Revised Jan 17, 2016; Accepted Jan 19, 2016

Corresponding author: Parisa Azimi

Functional Neurosurgery Research Center, Shahid Beheshti University of Medical Sciences, Tehran 198396-3113, Iran

Tel: +98-212-274-9204, Fax: +98-218-826-5188, E-mail: parisa.azimi@gmail.com 
able to assess low back disorder and disability for clinical or research purposes. The Oswestry disability index (ODI) and the Roland-Morris Disability Questionnaire (RMDQ) are two well-known instruments for measuring low back pain [5]. However, none of these tools can be considered as a golden standard [6].

The low back outcome score (LBOS) was developed as a quick and practical instrument to assess pain and functionality outcome in patients with low back pain $[7,8]$. The instrument is short and takes a few minutes to be completed. In addition the wording style is unique and very easy to understand. The scoring system of the instrument also is simple and according to respondents' score, it can be categorized $[7,8]$.

Although many investigators have used the LBOS [9$21]$, only one validation study has reported on the psychometric properties of the LBOS for non-English language patients [22]. The objectives of this study were to translate the LBOS from English into Persian (Iranian language), to validate the questionnaire, and to use it in studies of functionality and pain assessment for LDH patients in Iran.

\section{Materials and Methods}

\section{Questionnaire}

The LBOS consists of 13 questions and focuses on the subjective evaluation of pain intensity and limitations on spinal function experienced at different situations including activities related to work, house chores, sport, social life, and rest. It additionally evaluates the use of analgesics, sexual activity, sleep, walking, traveling, and getting dressed [7]. The possible score on the questionnaire ranges from 0 to 75 , where a higher score indicates a better condition (Appendix 1) [7,8]. The LBOS score can be categorized into four grade classifications: excellent $\geq$ 65; good 50-64; fair 30-49, and poor 0-29.

\section{Translation}

Based on Beaton's Guideline [23], the 'forward-backward' procedure was applied to translate the LBOS from English into Persian. Two general practitioners translated the questionnaire into Persian. One translator was aware of the project and the other translator was not. Both translators were instructed to aim for conceptual rather than literal translation [23]. Together with the main investigator
(P.A.) the translators compared the translations and produced a single provisional version of the questionnaire. Then, two other professional translators translated the provisional Persian questionnaire back into the English language. Finally, an expert committee consisting of the translators, researchers, and an outcome methodologist reviewed the translation process and the pre-final Persian version of the questionnaire was provided.

\section{Face validity}

A number of patients with low back pain completed the pre-final Persian version of the LBOS to establish that this version could be understood and that the questions measured what they were intended to measure. For each item patients were asked to respond to the following questions: "Do you understand what this means?" and "What does this mean to you by your own words?". Most patients correctly understood the questionnaire and the concept of each item. However, their general comments on difficulty in completing the questionnaire or understanding the texts were examined, and after a consensus by authors the final version was developed and used in this study. The Persian translation of the LBOS questionnaire is shown in Appendix 2.

\section{Patients and data collection}

The final draft of the Iranian version was administered to a sample of newly diagnosed patients with a single-level disc herniation attending the neurosurgery clinic of a large teaching hospital in Tehran, Iran. Patients who had lateral or central stenosis of spinal canal, previous spine surgery, recurrent lumbar disk herniation were excluded. For all participants, the LBOS was recorded at three points in time: preoperative and twice within 1-week interval after surgery.

\section{Surgery procedure}

Standard open lumbar discectomy was used. This procedure has been used to manage LDH in patients who have persistent symptoms of the condition that do not improve with a conservative treatment [24].

\section{Additional measures}

(a) The Iranian version of the ODI and the Finneson- 
Cooper score were also used. The Iranian ODI is a measure of functionality and contains 10 items. Possible scores range from 0 to 50, with higher scores indicating worst conditions. The psychometric properties of Iranian version of questionnaire are well documented [5]. The questionnaire was used to examine criterion validity. (b) The FinnesonCooper score is a lumbar disc surgery predictive score that was developed to assess potential candidates for excision of a herniated lumbar disc [25]. Scores range from 0 to 100 . Based on score, candidates are categorized as good (>75), fair (65-75), marginal (55-64), and poor $(<55)$.

\section{Statistical analyses}

In addition to descriptive analyses reporting number, frequency, mean, $t$-test and chi-square test, the following analyses were performed to assess psychometric properties of the LBOS.

\section{1) Reliability}

Internal consistency of the questionnaire was measured using the Cronbach's alpha coefficient and alpha $\geq 0.70$ was considered satisfactory [26]. In addition, to assure stability of measurement over time, test-retest reliability was assessed by comparing the LBOS scores at two postoperative assessments using the intraclass correlation coefficients (ICCs). An ICC above 0.80 was considered evidence of excellent stability [26].

\section{2) Validity}

Validity was assessed performing convergent validity. The correlation between the LBOS and the ODI was assessed using Pearson's correlation coefficient in order to assess criterion validity. Values $\geq 0.40$ were considered satisfactory ( $r \geq 0.81-1.0$ as excellent, $0.61-0.80$ very good, $0.41-0.60$ good, $0.21-0.40$ fair, and $0.0-0.20$ poor) [27]. In addition, known-groups comparison analysis was performed to test how well the questionnaire discriminates between subgroups of patients who differed in the Finneson-Cooper score. We hypothesized that patients with a Finneson-Cooper "good' grade would achieve a lower increase in the LBOS score compared with cases with a Finneson-Cooper 'fair' grade.

\section{3) Responsiveness to change}

Responsiveness as a psychometric property of the questionnaire was also assessed. Preoperative and postopera-
Table 1. Characteristics of the study sample of patients with lumbar disc herniation $(n=163)$

Characteristic Number (\%)

Age groups (yr)

\begin{tabular}{lc}
\hline Mean (SD) & $49.8(10.1)$ \\
\hline Range & $21-76$ \\
\hline Sex & \\
\hline Male & $73(44.8)$ \\
\hline Female & $90(55.2)$ \\
\hline Educational status & \\
\hline Illiterate & $24(14.7)$ \\
\hline Primary & $77(47.2)$ \\
\hline Secondary & $43(26.4)$ \\
\hline College/university & $19(11.7)$ \\
\hline Marital status & \\
\hline Single & $35(21.5)$ \\
\hline Married & $110(67.5)$ \\
\hline Divorced/widowed & $18(11.0)$ \\
\hline Levels of lumbar disc hernia & \\
\hline L3-4 & $14(8.6)$ \\
\hline L4-5 & $84(51.5)$ \\
\hline L5-S1 & $65(39.9)$ \\
\hline Finneson-Cooper score & $105(64.4)$ \\
\hline Good & $58(35.6)$ \\
\hline Fair & \\
\hline Oswestry disabity index & \\
\hline
\end{tabular}

Oswestry disabilty index

\begin{tabular}{lc} 
Preoperative & $29.4(10.8)$ \\
\hline Mean (SD) & $18-50$ \\
\hline Range & \\
\hline Postoperative & $15.3(10.9)$ \\
\hline Mean (SD) & $0-26$ \\
\hline Range & \\
Low back outcome score & \\
\hline Preoperative & $2(1.2)$ \\
\hline Excellent & $14(8.6)$ \\
\hline Good & $82(50.3)$ \\
\hline Fair & $65(39.9)$ \\
\hline Poor & \\
\hline Postoperative & $105(64.4)$ \\
\hline Excellent & $41(25.2)$ \\
\hline Good & $11(6.7)$ \\
\hline Fair & $6(3.7)$ \\
\hline Poor & \\
\hline
\end{tabular}

SD, standard deviation. 
Table 2. The total LBOS score by Finneson-Cooper score (known-groups comparison)

\begin{tabular}{lccc} 
LBOS score & Good (Finneson-Cooper score $>75)$ & Fair (Finneson-Cooper score 65-75) & $p$-value \\
\hline Total score & $24.5(6.8)$ & $33.5(3.4)$ & $<0.001$ \\
\hline
\end{tabular}

LBOS, low back outcome score.

Table 3. The LBOS responsiveness to change

\begin{tabular}{|c|c|c|c|}
\hline & Preoperative & Postoperative & \\
\hline & Mean (SD) & Mean (SD) & \\
\hline Current pain & $0.9(1.0)$ & $7.8(1.0)$ & $<0.001$ \\
\hline Employment & $2.7(0.8)$ & $6.4(2.2)$ & 0.001 \\
\hline Domestic chores or odd jobs & $2.4(0.7)$ & $5.1(2.1)$ & 0.001 \\
\hline Sport or active social activities & $2.7(0.6)$ & $5.2(2.6)$ & 0.001 \\
\hline Resting & $3.2(0.8)$ & $5.1(0.7)$ & 0.001 \\
\hline Treatment or consultation & $2.1(0.4)$ & $5.2(0.4)$ & 0.001 \\
\hline Analgesia & $2.2(0.7)$ & $5.8(0.2)$ & 0.001 \\
\hline Sex life & $4.1(0.3)$ & $5.4(0.6)$ & 0.001 \\
\hline Sleeping & $1.8(0.2)$ & $2.7(0.1)$ & 0.001 \\
\hline Walking & $1.2(0.6)$ & $2.8(0.2)$ & 0.001 \\
\hline Sitting & $1.7(0.9)$ & $2.9(0.1)$ & 0.001 \\
\hline Travelling & $1.3(0.5)$ & $2.8(0.3)$ & 0.001 \\
\hline Dressing & $1.4(0.5)$ & $2.6(0.3)$ & 0.001 \\
\hline Total & $27.7(8.7)$ & $59.8(12.3)$ & 0.001 \\
\hline
\end{tabular}

LBOS, low back outcome score; SD, standard deviation.

${ }^{\text {al)} D e r i v e d ~ f r o m ~ p a i r e d ~ s a m p l e s ~} t$-test.

tive scores were compared using the paired $t$-test to examine whether the LBOS was able to capture the change after intervention (surgery).

\section{Ethics}

The Ethics Committee of Shahid Beheshti University of Medical Sciences approved the study.

\section{Results}

In all, 163 patients completed the questionnaire. The characteristics of patients and their scores on the LBOS are shown in Table 1. The mean age of patients was 49.8 (standard deviation $=10.1$ ) years; most were married (67.5\%) and had completed primary or secondary education (73.6\%). Patients had open discectomy and were distributed from L3 to S1 levels. The ODI scores for the study sample also are shown in Table 1.
The internal consistency of the LBOS as measured by the Cronbach's alpha coefficient was 0.77 at preoperative assessment and 0.79 at postoperative evaluation indicating a satisfactory reliability. Further analysis also indicated that the test-retest ICC (95\% confidence interval) was $0.82(0.62-0.91)$ for the LBOS total, lending support to its good reliability.

Validity of the LBOS was examined using the known groups comparison. The patients' rating on the LBOS assessments discriminated well between sub-groups of patients who differed in the Finneson-Cooper score. The PSQ score was significantly lower for those who were identified as 'good' by the Finneson-Cooper score, as hypothesized $(p<0.001)$ (Table 2$)$. In addition, validity of the LBOS was examined using convergent validity. Total score of the LBOS correlated strongly with total score of the ODI lending support to its good convergent validity $(r=-0.83 ; p<0.001)$.

Responsiveness to change was assessed by paired $t$-test. 
In all instances the LBOS was able to detect changes after intervention (surgery) indicating improvements in all subscales as expected (Table 3 ).

\section{Discussion}

This study is the first to report on translation and validation of the LBOS in Iran. The Persian version of the LBOS is a reliable measure to evaluate back pain in Iranian patients with $\mathrm{LDH}$, with excellent internal consistency. The Cronbach's alpha value in our study was comparable with the original version of the LBOS, with reported values of 0.85 [8] and 0.77 [21]. The LBOS also showed excellent test-retest reliability, comparable with the test-retest reliability of the original English versions [8]. However, Misterska et al. [22] reported poor test-retest reliability (0.34). They indicated that the test-retest values of five items (employment, domestic chores, sports, sex life, and sleeping) exceeded 0.4, which were adequate [22]. Muller et al. [15] evaluated the validity, reliability, availability and comparability for the nine most widely used outcome tools: ODI, RMDQ, LBOS, Quebec Back Pain Disability Scale (QBPDS), million visual analogue scale (MVAS), Aberdeen low back disability scale (ALBDS), North American Spine Society (NASS) Lumbar Spine Outcome Assessment Instrument (NASS LSO), low back pain rating Scale (LBPRS), and Waddell disability index (WDI). Of these, the ODI, RMDQ, LBOS, QBPDS, and WDI provided crucial data on the minimum clinically important difference [15]. In addition, the authors recommended the LBOS as a short general assessment for backache, pain medication, ability to work, and leisure activities [16]. Comparing the results with findings from Iranian low back patients using the ODI and the RMDQ [5], and the STarT Back Screening Tool (SBST) [28] presently revealed nearly identical or better findings.

We used the Finneson-Cooper score as a clinical measure for known-groups comparison. Patients who differed in Finneson-Cooper score assessments scored differently on the LBOS score, as expected, supporting the discriminant validity of the LBOS score. Interestingly, the LBOS score was lower in the group with 'good' Finneson-Cooper score compared to those identified as 'fair'. In addition, significant correlations were found between the LBOS and the ODI. These results match the good construct validity reported in a similar study from Poland by Misterska et al. [22], and original version of LBOS $[8,15]$. The findings from this study suggest that the Persian version of the questionnaire has a good construct and could be regarded as a valid measure.

The results of the current study showed that the LBOS is an outcome measure that assesses both the pain and functionality of back pain of patients with LDH for which acceptability, reliability, validity, and responsiveness to change have been demonstrated. It is a quick and effective alternative in daily clinical practice to assess the condition of patients.

We performed a number of limited tests to carry out this validation study. In future it might be necessary to perform other statistical tests to establish stronger psychometric properties for the LBOS score. In addition, further investigation of the psychometric properties of the LBOS is needed in different spinal conditions, in patients with the variety of $\mathrm{LDH}$, and more importantly in normal healthy people.

\section{Conclusions}

The Iranian version of LBOS is a valid and reliable instrument for back pain assessment in patients with LDH.

\section{Conflict of Interest}

No potential conflict of interest relevant to this article was reported

\section{Acknowledgment}

The authors thank the staff of the Neurosurgery Unit Imam-Hossain Hospital, Tehran, Iran.

\section{References}

1. Kordi R, Rostami M. Low back pain in children and adolescents: an algorithmic clinical approach. Iran J Pediatr 2011;21:259-70.

2. Fardon DF, Milette PC; Combined Task Forces of the North American Spine Society, American Society of Spine Radiology, and American Society of Neuroradiology. Nomenclature and classification of lumbar disc pathology. Recommendations of the Combined task Forces of the North American Spine Society, American Society of Spine Radiology, and American Society of Neuroradiology. Spine (Phila Pa 1976) 
2001;26:E93-113.

3. Hoy D, Bain C, Williams G, et al. A systematic review of the global prevalence of low back pain. Arthritis Rheum 2012;64:2028-37.

4. Tsuboi H, Takeuchi K, Watanabe M, Hori R, Kobayashi F. Psychosocial factors related to low back pain among school personnel in Nagoya, Japan. Ind Health 2002;40:266-71.

5. Mousavi SJ, Parnianpour M, Mehdian H, Montazeri A, Mobini B. The Oswestry Disability Index, the Roland-Morris Disability Questionnaire, and the Quebec Back Pain Disability Scale: translation and validation studies of the Iranian versions. Spine (Phila Pa 1976) 2006;31:E454-9.

6. Niskanen RO. The Oswestry Low Back Pain Disability Questionnaire: a two-year follow-up of spine surgery patients. Scand J Surg 2002;91:208-11.

7. Greenough CG, Fraser RD. Assessment of outcome in patients with low-back pain. Spine (Phila Pa 1976) 1992;17:36-41.

8. Holt AE, Shaw NJ, Shetty A, Greenough CG. The reliability of the Low Back Outcome Score for back pain. Spine (Phila Pa 1976) 2002;27:206-10.

9. Gregg CD, McIntosh G, Hall H, Watson H, Williams D, Hoffman CW. The relationship between the Tampa Scale of Kinesiophobia and low back pain rehabilitation outcomes. Spine J 2015;15:2466-71.

10. Gunzburg R, Keller TS, Szpalski M, Vandeputte K, Spratt KF. Clinical and psychofunctional measures of conservative decompression surgery for lumbar spinal stenosis: a prospective cohort study. Eur Spine J 2003;12:197-204.

11. Been HD, Poolman RW, Ubags LH. Clinical outcome and radiographic results after surgical treatment of post-traumatic thoracolumbar kyphosis following simple type A fractures. Eur Spine J 2004;13:101-7.

12. Spratt KF, Keller TS, Szpalski M, Vandeputte K, Gunzburg R. A predictive model for outcome after conservative decompression surgery for lumbar spinal stenosis. Eur Spine J 2004;13:14-21.

13. Penta M, Fraser RD. Anterior lumbar interbody fusion: a minimum 10-year follow-up. Spine (Phila Pa 1976) 1997;22:2429-34.

14. Woertgen C, Holzschuh M, Rothoerl RD, Brawanski A. Does the choice of outcome scale influence prognostic factors for lumbar disc surgery? A prospective, consecutive study of 121 patients. Eur Spine J 1997;
6:173-80.

15. Muller U, Duetz MS, Roeder C, Greenough CG. Condition-specific outcome measures for low back pain. Part I: validation. Eur Spine J 2004;13:301-13.

16. Muller U, Roeder C, Dubs L, Duetz MS, Greenough CG. Condition-specific outcome measures for low back pain. Part II: scale construction. Eur Spine J 2004;13:314-24.

17. Tafazal SI, Sell PJ. Outcome scores in spinal surgery quantified: excellent, good, fair and poor in terms of patient-completed tools. Eur Spine J 2006;15:165360.

18. Jang KS, Kim HS, Ju CI, Kim SW, Lee SM, Shin H. Paraspinal muscle sparing versus percutaneous screw fixation : a prospective and comparative study for the treatment of L5-S1 spondylolisthesis. J Korean Neurosurg Soc 2011;49:163-6.

19. Kim HS, Park KH, Ju CI, Kim SW, Lee SM, Shin H. Minimally invasive multi-level posterior lumbar interbody fusion using a percutaneously inserted spinal fixation system : technical tips, surgical outcomes. J Korean Neurosurg Soc 2011;50:441-5.

20. Lee GJ, Lee JK, Hur H, Jang JW, Kim TS, Kim SH. Comparison of clinical and radiologic results between expandable cages and titanium mesh cages for thoracolumbar burst fracture. J Korean Neurosurg Soc 2014;55:142-7.

21. Akgun B, Kaplan M, Arici L, Pusat S, Erol FS. Low back pain and sciatica related with the premenstrual period in patients with lumbar disc herniation. Turk Neurosurg 2010;20:437-41.

22. Misterska E, Jankowski R, Glowacki M. Quebec Back Pain Disability Scale, Low Back Outcome Score and revised Oswestry low back pain disability scale for patients with low back pain due to degenerative disc disease: evaluation of Polish versions. Spine (Phila Pa 1976) 2011;36:E1722-9.

23. Guillemin F, Bombardier C, Beaton D. Cross-cultural adaptation of health-related quality of life measures: literature review and proposed guidelines. J Clin Epidemiol 1993;46:1417-32.

24. Spengler DM, Ouellette EA, Battie M, Zeh J. Elective discectomy for herniation of a lumbar disc. Additional experience with an objective method. J Bone Joint Surg Am 1990;72:230-7.

25. Finneson BE, Cooper VR. A lumbar disc surgery predictive score card: a retrospective evaluation. Spine 
(Phila Pa 1976) 1979;4:141-4.

26. White P, Lewith G, Prescott P. The core outcomes for neck pain: validation of a new outcome measure. Spine (Phila Pa 1976) 2004;29:1923-30.

27. Nunnally JC, Bernstein IH. Psychometric theory. 3rd ed. New York: McGraw-Hill; 1994.
28. Azimi P, Shahzadi S, Azhari S, Montazeri A. A validation study of the Iranian version of STarT Back Screening Tool (SBST) in lumbar central canal stenosis patients. J Orthop Sci 2014;19:213-7. 
Appendix 1. Low back outcome score

\begin{tabular}{|c|c|}
\hline Parameter (finding) & Points \\
\hline \multicolumn{2}{|l|}{ Current pain } \\
\hline 7 to $10 \mathrm{~cm}$ VAS & 0 \\
\hline 5 to $6 \mathrm{~cm}$ VAS & 3 \\
\hline 3 to $4 \mathrm{~cm}$ VAS & 6 \\
\hline 0 to $2 \mathrm{~cm}$ VAS & 9 \\
\hline \multicolumn{2}{|l|}{ Employment } \\
\hline Unemployed because of back pain & 0 \\
\hline Part time & 3 \\
\hline Full time lighter & 6 \\
\hline Full time original & 9 \\
\hline \multicolumn{2}{|l|}{ Domestic chores or odd jobs } \\
\hline None & 0 \\
\hline A few but not many & 3 \\
\hline Most or all but more slowly & 6 \\
\hline Normally & 9 \\
\hline \multicolumn{2}{|l|}{ Sport or active social activities } \\
\hline None & 0 \\
\hline Some but much less than before & 3 \\
\hline Back to previous level & 9 \\
\hline \multicolumn{2}{|l|}{ Resting } \\
\hline Resting more than half the day & 0 \\
\hline Little rest needed occasional & 4 \\
\hline No need to rest & 6 \\
\hline \multicolumn{2}{|l|}{ Treatment or consultation } \\
\hline More than once per month & 0 \\
\hline About once per month & 2 \\
\hline Rarely & 4 \\
\hline Never & 6 \\
\hline \multicolumn{2}{|l|}{ Analgesia } \\
\hline Several times each day & 0 \\
\hline Almost every day & 2 \\
\hline Occasionally & 4 \\
\hline Never & 6 \\
\hline \multicolumn{2}{|l|}{ Sex life } \\
\hline Severely affected impossible & 0 \\
\hline Moderately affected difficult & 2 \\
\hline Mildly affected & 4 \\
\hline Unaffected & 6 \\
\hline \multicolumn{2}{|l|}{ Sleeping } \\
\hline Severely affected impossible & 0 \\
\hline Moderately affected difficult & 1 \\
\hline Mildly affected & 2 \\
\hline Unaffected & 3 \\
\hline \multicolumn{2}{|l|}{ Walking } \\
\hline Severely affected impossible & 0 \\
\hline Moderately affected difficult & 1 \\
\hline Mildly affected & 2 \\
\hline Unaffected & 3 \\
\hline \multicolumn{2}{|l|}{ Sitting } \\
\hline Severely affected impossible & 0 \\
\hline Moderately affected difficult & 1 \\
\hline Mildly affected & 2 \\
\hline Unaffected & 3 \\
\hline \multicolumn{2}{|l|}{ Travelling } \\
\hline Severely affected impossible & 0 \\
\hline Moderately affected difficult & 1 \\
\hline Mildly affected & 2 \\
\hline Unaffected & 3 \\
\hline \multicolumn{2}{|l|}{ Dressing } \\
\hline Severely affected impossible & 0 \\
\hline Moderately affected difficult & 1 \\
\hline Mildly affected & 2 \\
\hline Unaffected & 3 \\
\hline
\end{tabular}

VAS, visual analogue scale. 
Appendix 2.

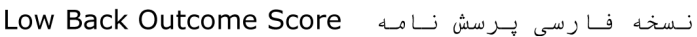

\begin{tabular}{|c|c|c|}
\hline نـمـره & يـافـتــ & شـاخص \\
\hline & & درد در حال حـاضر \\
\hline 0 & 10 & \\
\hline 3 & 6 ت 5 & \\
\hline 6 & $4-3$ & \\
\hline 9 & $2 \sqcup 0$ & \\
\hline & & وضعيـت اشتـــال \\
\hline 0 & بـيكـار بـه دلـيـل كمـر درد & \\
\hline 3 & 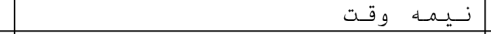 & \\
\hline 6 & تتـــام وقـت، امـا بـ كـار سبكتـر & \\
\hline 9 & تـمـام وقـت معمولى & \\
\hline & & وظـا يـف خـانــو ادمكى \\
\hline 0 & هي-ج & \\
\hline 3 & 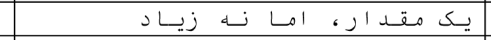 & \\
\hline 6 & 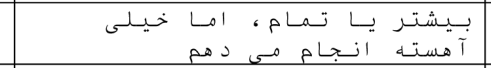 & \\
\hline 9 & wares & \\
\hline & & 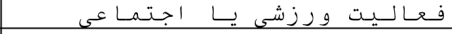 \\
\hline 0 & هـيـج & \\
\hline 3 & 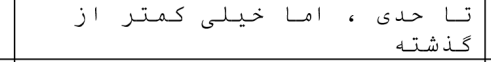 & \\
\hline 9 & مـــل قـبــل & \\
\hline & & استـر احت \\
\hline 0 & استـر احت بـــشتــر از نـصف روز & \\
\hline 4 & 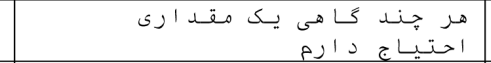 & \\
\hline 6 & نــــــاز بــهـ استـر احت نـــد ارم & \\
\hline & & 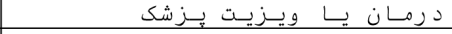 \\
\hline 0 & 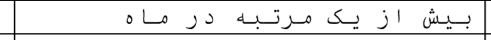 & \\
\hline 2 & يـك بــار در مـان & \\
\hline 4 & بـنــد رت & \\
\hline 6 & هـرَز & \\
\hline & & دردتفـاده از د اروهـاى ضد \\
\hline 0 & جهنـد بـار در روز & \\
\hline 2 & تــــريـب هـر روز & \\
\hline 4 & هـ & \\
\hline 6 & هـرگز & \\
\hline & & فـعـالــــت جنـسي \\
\hline 0 & بـشدت مشكل د ارم & \\
\hline 2 & تـا حدى مشكل د ارم & \\
\hline 4 & بـطور خفـيف مشكل د ارم & \\
\hline 6 & مـشكلى نـــ ارم & \\
\hline & & خو ابـيــن \\
\hline 0 & بـشدت مسكل د ارم & \\
\hline 2 & تـ حدى مـشكل د ارم & \\
\hline 4 & بـطور رخفيف مـشكل د ارم & \\
\hline 6 & مـشكـلى نــد ارم & \\
\hline & & 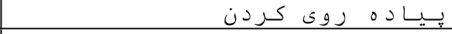 \\
\hline 0 & بـشدت مسكل د ارم & \\
\hline 2 & ت تـ حدى مـشكل د ارم & \\
\hline 4 & بـطور خفـيف مـشكل د ارم & \\
\hline 6 & مـشكـلى نـــ ارم & \\
\hline & & نـشستن \\
\hline 0 & بـشدت مشكل د ارم & \\
\hline 2 & تـا حدى مـشكل د ارم & \\
\hline 4 & بـطور خفـيف مـشكل د ارم & \\
\hline 6 & مـشكلمى نـــ ارم & \\
\hline & & مـسـا فـرت كـردن \\
\hline 0 & بـشـت مسشكل د ارم & \\
\hline 2 & تـا حدى مـشكل د ارم & \\
\hline 4 & بـطور خفـيف مـشكل د ارم & \\
\hline 6 & مـشكـلى نــــ ارم & \\
\hline & & 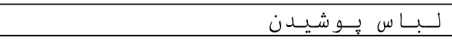 \\
\hline 0 & بـشدت مسكل د ارم & \\
\hline 2 & تـا حدى مششكل د ارم & \\
\hline 4 & بـطور خفيـف مشكل د ارم & \\
\hline 6 & مـشكلي نــد ارم & \\
\hline
\end{tabular}

